\title{
Enhancing the Implementation of Telecommuting (Work from Home) in Malaysia
}

\author{
Boon Heng Teh ${ }^{1}$, Patrick Chin Hooi ${ }^{1}$, Yin Lee Loh ${ }^{1}$, Tze San Ong ${ }^{2}$ \& Yong Hoe Hong ${ }^{1}$ \\ ${ }^{1}$ Faculty of Management, Multimedia University Malaysia, Cyberjaya, Malaysia \\ ${ }^{2}$ Department of Accounting and Finance, Faculty or Economics and Management, University Putra Malaysia, \\ Malaysia \\ Correspondence: Boon Heng Teh, Faculty of Management, Multimedia University Malaysia, Persiaran \\ Multimedia, 63100, Cyberjaya, Selangor, Malaysia. Tel: 60-3-8312-5052. E-mail: bhteh@mmu.edu.my
}

Received: February 4, 2013 Accepted: March 6, 2013 Online Published: May 2, 2013

doi:10.5539/ass.v9n7p1

URL: http://dx.doi.org/10.5539/ass.v9n7p1

\begin{abstract}
The telecommuting programme is nothing unusual in developed countries and it is proven benefit regardless of employee or employer perspective. However, this programme has not yet gained popularity in Malaysia. Currently, there are only some forms of telecommute practices and mainly carried out as unofficial agreement between staff and managers and not with the consent of the company administration. Therefore, it is necessary to look into this area particularly initiatives to increase the implementation of telecommuting in Malaysia. Hence, my research will examine in detail the steps and driving factors for telecommuting implementation in Malaysia. The study has revealed two significant driving factors for telecommuting implementation in Malaysia: (1) Job Satisfaction and Commitment and (2) Operating Cost Reduction. Complement with it, a detailed implementation steps for telecommuting have been described in this study, thus providing detailed guidance and reference for any firms who are implementing or planning to implementing a telecommuting programme.
\end{abstract}

Keywords: telecommuting, work from home, job satisfaction and commitment, operating cost reduction, implementation, Malaysia

\section{Introduction}

World at Work, a respectable professional group that dealing with human capital management, has come out with a report related to Telecommuting (Teh, Loh, \& Ong, 2012). According to the professional group, key telecommuting can be delineated as:

1) Companies escalating telecommuting opportunities

2) The increasing of telecommuting

3) Surge in broadband usage for home-based teleworkers

4) Countless wireless usage among teleworkers

5) Staffs increasingly operating from anywhere

\subsection{Setting an Agenda}

The telecommuting programme is nothing unusual in developed countries. Moreover, it has even been practised by developing countries like Malaysia, Philippines and Thailand. The telecommuting programme has been implemented by many international organisations worldwide such as Microsoft, IBM, HP and Accenture to gain competitive advantages. This programme is popular among the information technologies companies due to its flexibility in working hours. For instance, SCOPE International Sdn Bhd, which is a subsidiary company of Standard Chartered Bank of UK operating in Malaysia, is one of the local Information Technologies companies that has promoted a telecommuting programme as an official programme to all its staff with the aim of encouraging work-life balance.

Similarly,the Prime Minister of Malaysia, YAB Dato' Sri Mohd. Najib Tun Abdul Razak, called for the transformation of economy, society and government, in order to ensure the goals of a high income nation in 2020 are achieved within the stipulated timeframe. According to Prime minister, the measures to achieve high-income 
status must be sustainable in economic, social and environmental terms (Pemandu, 2010). Critically, retaining and attracting talent is crucial to achieving a high income nation under the Economic Transformation Programme. Adhere with it Talent Corporation has been established by the Government of Malaysia to achieve the abovementioned goals.

Furthermore, the participation of Malaysian women in the workforce is growing. Hence, effective human capital management should be prioritised to ensure the sustainable development particularly of the Malaysian workforce under the Economic Transformation Programme. In this context, not only a competitive wage package but also a conducive working environment should be embedded into the Malaysian workforce (Pemandu, 2010).

In a nutshell, telecommuting (work from home) is deemed to be a vital component in producing a competitive and conducive working environment.

According to Mohammad et al. (2000), via telecommuting, companies able to recruit and retain key employees. Furthermore, Hjorthol and Nossum (2008) have proven that telecommuting can allow workers to address both their family needs and corporate task, which is very crucial to retaining a talented workforce particularly women. Moreover, Diane and Emilie (2007) and Dubrin (1991) have pinpointed that telecommuting not only increases workforce productivity but also satisfaction.

\subsection{Research Problem Statement}

Even though telecommuting is of proven benefit regardless of employee or employer perspective, this programme has not yet gained popularity in Malaysia. There are, however, some forms of telecommute practices, but these are mainly carried out as unofficial agreement between staff and managers and not with the consent of the company governors or administration.

Therefore, it is necessary to look into this area particularly initiatives to increase the implementation of telecommuting in Malaysia. Hence, my research examines in detail the steps and driving factors for telecommuting implementation in Malaysia.

\subsection{Research Question}

1) What are the implementation steps for telecommuting?

2) What are the critical driving factors for telecommuting implementation in Malaysia?

\subsection{Research Objective}

The objectives of this research are:

1) To discuss the advantages, disadvantages, difficulties and challenges associated to the telecommuting programme as well as the driving factors.

2) To examine the critical implementation steps for the telecommuting adoption.

3) To determine the critical driving factors for telecommuting implementation in Malaysia.

\subsection{Significance of the Study}

This study is very significant as the findings could escalate the telecommuting implementation in Malaysia. Widespread implementation of telecommuting will enhance Malaysian labour competiveness particularly in terms of labour flexibility and productivity. Hence, it definitely aligns with the Malaysian Transformation Programme which emphasises sustainable development.

\section{Literature Review}

\subsection{The Advantages of Telecommuting Implementation}

In research carried out by Hjorthol and Nossum (2009), it was revealed that the most important reason for working at home relates to family needs. Employees choose to telecommute because their children are sick, have taken days off school or they need to take children to school.

Similar findings were made by Mohammad et al. (2000); one of the important reasons for women preferring to work at home is to be near their family. Telecommuting allows single parents to have the flexibility of integrating work and child care. As the population ages, employees may also be responsible for caring for elderly parents as well.

In addition, telecommuting is perceived as a mechanism that can increase job satisfaction. According to DuBrin (1991), working conditions, scheduling of own working hours and taking care of family/personal responsibilities were the ingredients of job satisfaction. All can be achieved via telecommuting. 
Telecommuting has been used successfully to allow employees with conditions such as chronic fatigue syndrome or multiple sclerosis to work at home and lead more productive lives (Muhammad, 2000).

As argued by Diane and Emilie (2007), and proven by previous studies, telecommute could motivate staff. Their finding shows that the demand for telecommuting is mainly justified by flexibility and quality of life, productivity and avoidance of commuting. In short, employees are more efficient at home than when they work at the client's office as home provides a quiet and peaceful working environment with fewer disturbances. This contributes to increased productivity.

Kurland and Bailey (1999) defined telecommuting as the elimination of commute time, the rise in perceived autonomy and control, the invisibility that reduces the need for special clothing and the absence of office politics (Margaret, 2002). Furthermore, they concluded that work-life balance is indeed a benefit of telecommuting and the significant effect is primarily for "dual-career families" (Samia and Richard, 2006).

It is also found that productivity can be increased as a result of eliminating the wasted time that a real commute requires (Davis, 1995; Hill et al., 1998). The telecommuting programme can be used to reduce traffic jams and improve air quality (Siha et al., 2006).

Hence, the telecommuting programme is seen not only as beneficial to employees and employers around the world but also to society. According to Devito (1997), a 10 percent reduction in daily commuting in densely populated areas can have a significant effect on air quality (Mohammad et al, 2000).

Even though telecommute is not a necessity in the Business Continuity Plan, but rather a critical aspect (David Honour, 2005), in any circumstance where the office is not able to function, the employees can carry out their duty by telecommute.

\subsection{The Disadvantages of Telecommuting Implementation}

Conversely, several shortages may hinder the telecommuting implementation.

From employer perspective, the main problematic is inability of superior to physically monitor their subordinates' performance. Furthermore, team synergy is difficult to be generated as teleworking will adversely affect the social network among the employee by disrupting teamwork spirit (Wang, Zhang and Xu; 2004).

From employee perspectives, teleworkers may subject to limited resources while discharging duty compare to their office peers, since resources and support services are not accessible at home. Telecommuting may result a steady degradation of a person's ability to communicate with others (Wang, Zhang and $\mathrm{Xu}$; 2004).

The introduction of mobile broadband is a gift for the telecommuting community, but many would argue that working in a public network makes hacking and the spread of malicious codes easier. The findings gathered by Clear et al. (2005) suggest that data security might be an indicator to measure successful telecommuting implementation.

Telecommuting practice may not be adaptable by everyone. Home-based telecommuters need to rely on their self-discipline to devise a temporal structure for their days spent at home. In the absence of any external, default signals, they have to act as both control and executing authority of internalised time-disciplines at the same time (Susanne \& Gilll, 2003; Diane, 2008)

\subsection{The Difficulties and Challenges of Telecommuting Adoption}

Though the motivation for telecommuting is mostly positive, there are many known issues arising from the telecommuting programme.

In the home-based work setting, boundaries between work and family life will blur and eventually affect productivity, as there is a problem related to the difficulty in establishing boundaries between work, family and leisure (Sakamoto \& Spinks, 2008). The same observation has been made by Diane-Gabrielle Tremblay et al. (2007).

Telecommuting practice may not be adaptable by everyone. Home-based telecommuters need to rely on their self-discipline to devise a temporal structure for their days spent at home. In the absence of any external, default signals, they have to act as both control and executing authority of internalised time-disciplines at the same time (Susanne \& Gilll, 2003; Diane, 2008).

Svein (2007) draws a conclusion that not all jobs and not all people have a potential for telecommuting. Over the years there has been more focus on work-task than complete jobs; that is to say, certain work tasks but not the whole job are relevant for telecommuting. These jobs include sales, consulting, writing and research analysis, all of which can be conducted outside the traditional office environment (Mohammad, Marilyn \& Tammy, 2000). 
"How can I know that they are working on when I cannot see them?" (Kugelmass, 1995). Likewise, Mohammad (2000) pointed out that trust can be a stumbling block to many telecommuting activities.

The workers need first to develop a relation of trust with their client before asking for telecommuting. Otherwise, clients will tend to refuse this work arrangement in spite of its advantages for both parties (Diane \& Emilie, 2007). Trust becomes essential and so too practical suggestions on how workers and managers can better manage their separation (Kurland \& Bailey, 1999)

\subsection{The Driving Factors for Telecommuting Adoption}

Guimaraes and Dallow (1999) empirically tested the success factors for telecommuting programmes. They found that the characteristics of supervisors, employees, tasks and work environment are positively related to the success of the programme. They also emphasised the importance of planning, management support and employees' selection (Samia \& Richard, 2006).

Another critical success factor for the telecommuting programme implementation is trust. In fact, Cascio (2000) and Jonathan (2001) argue that if there is a lack of trust, telecommuting will not be successful even if everything else is perfectly in place. Trust is clearly an important factor in a telecommuting situation; research (Staples, 2001) has shown that in remote work situations trust is positively related to perceptions of good performance and job satisfaction and negatively related to job stress (Kellyman \& Jennifer, 2005).

Support in the form of training is also critical for telecommuting success. Training must be supported by top management and should be provided for both telecommuters and their managers (Potter, 2003). Results of a study by Hill et al. (1998) on the virtual workplace of IBM employees showed that having good training is essential for both managers and telecommuters (Kellyman \& Jennifer, 2005).

A survey of Telecommuters in the UK, Ireland and Europe found telecommuting was more likely to be successful when the worker had Positive skills in self-management, the organisation had supportive systems in place and both understood and approved the communication structure (Patrickson, 2002).

According to Siha and Monroe (2006), potential productivity increase is the key to company decisions to utilise telecommuting. As long as jobs and people are selected carefully for telecommuting, any concerns over productivity are mitigated. These jobs include sales, consulting, writing and research analysis, all of which can be conducted outside the traditional office environment (Mohammad et al, 2000).

On the other hand, according to Svein (2007), the distance and the use of ICT have naturally integrated in the organisations' structure due to specialisation and globalisation. This is seen as one of the motivation factors of telecommute. Management over distances in separated locations and the use of ICT have become normality in the working environment.

Telecommuters who receive adequate technological support have been found to be more satisfied with their telecommuting experience than those who do not (Haines et al, 2002). For the telecommuting programme to be successful, an organisation needs to provide technology and technological support for telecommuters (Fritz et al, 1998, Mann et al, 2000, Ward \& Shabha, 2001). Also, based on the research by Watad and DiSanzo (2000), top management support, comprehensive training, deployment of reliable IT architecture in less than six months and addressing technical and personal issues immediately are critical factors for telecommuting programme implementation (Samia \& Richard, 2006).

\section{The Implementation Steps for Telecommuting Implementation}

The implementation steps are adopted from canonical action research guidelines which were described in the literature reviewed. Canonical action research was selected as a reference due to the fact that its step by step process is a much clearer approach as demonstrated by Raman, Ryan and Olfman (2006).

\subsection{Identify Issues}

No standardisation of remote access meant that physical facilities were not centrally managed thus giving a different set of configurations for every device. These issues resulted in difficulty managing and supporting employees and caused them frustration in their attempt to make use of this facility. As a result, the implementation of this remote access technology was only adopted by a few.

Another issue was data security which was at risk since employees were using their own personal notebooks or desktop computers to access the organisation network. Successful malicious attacks are more frequent on personal devices since most of the time these are not properly equipped with adequate software and computer policy settings. Data security involves the prevention of data theft which are activities related to malicious attacks or unauthorised entry to gain access to sensitive organisation data. 
It was noted from the issues identification process that the main organisational issues were as follows:

1) The lack of standardisation of available remote access facility.

2) Data security with regard to the use of personal devices to access the organisation's network.

\subsection{Task Identification}

The following table 1 provides a summary of the critical tasks related to the major organisational departments. It provides useful information to identify the physical requirements of telecommuting.

Table 1. Task identification

\begin{tabular}{lll}
\hline Department & Task & \\
\hline Finance & 1. & Salary payment \\
& 2. & Duty travel processing \\
Human Resources & 3. & Vendor payment \\
& 1. & Contract management \\
Procurement & 2. & Leave management \\
Information & 1. & Invoice processing \\
Technology & 1. & Incident management \\
\hline
\end{tabular}

\subsection{Drafting of Telecommuting Policy}

A telecommuting policy should be created as a guideline for the employees who will be involved in the telecommuting scheme, in order to ensure appropriate usage and compliance with the organisational operation and data protection principles, as well as to safeguard the equipment.

\subsection{Assessment of Information Technology (IT) Systems}

Assessment of the organisational IT system should be performed to evaluate the level of practicality of implementing telecommuting with the available system. The following is a list of the core IT services:

\subsubsection{Enterprise Resource Planning (ERP) System}

The ERP solution is the most critical component of the organisation as all administrative related processes mentioned earlier have to be administered by the system. For the general staff members, the ERP system serves as a one stop self-service location to manage their employment information, leave requests, purchase requests, travel requests, etc.

\subsubsection{Ticketing System}

The ticketing system is closely related to the ERP system. The ticketing system handles all requests concerning the processes. This also includes request for IT related support. For a request to be valid it must be entered and delivered through the ticketing system.

\subsubsection{Managed Workstation}

The machines in the organisation are centrally managed by the IT department. One of the most important components of a managed workstation is probably the implementation of a standard computer policy which attempts to maximise the security perimeters of the environment.

\subsubsection{Network and Infrastructure Connectivity}

To ensure the smooth running of operations, this service aims to monitor and maintain the organisation connectivity by liaising with third party Internet Service Providers (ISP). This service also provides access to the organisation network, and is responsible for ensuring infrastructure that is hosting services, for example, file sharing and server hosting.

\subsubsection{Communications}

E-mail and Voice over Internet Protocol (VoIP) are two of the most important means of communication for the employees of an organisation. E-mail, however, is the most important since it is the most used form of communication. It is closely tied to the ERP and ticketing system. 
Another essential part of communication is VoIP. Combination of both e-mail and VoIP makes the process of delivering and sharing information more effective. It is mandatory that every employee is equipped with an IP phone with his or her own extension. A VoIP client will be used to enable employees to call into the organisation phone line. In order to connect, the employee will be required to dial the extension that is desired. This is a simple and cost effective solution compared with providing employees with mobile phones to call into the office.

\subsection{Telecommuting Requirements}

The next step is to identify requirements for telecommuting.

\subsubsection{Platform for Applications}

The notebook is one of the mobile devices available currently in the market. It was chosen from among other devices such as smartphones and tablets due to the fact that the organisational system is compatible with the operating system, which was only available the notebooks at the time. The machines are standardised to ensure that it is compatible with the ERP system and ticketing system. This also ensures that proper computer policies are applied to maintain data security of the organisation.

\subsubsection{Internet Connectivity}

To provide mobility and flexibility, employees were provided with a $3 \mathrm{G}$ broadband dongle. This is to enable them to connect to the Internet anytime and anywhere. It is important to note that some of the employees resorted to their private broadband for connectivity since the mobile broadband coverage was still limited to a few selected geographical locations.

\subsubsection{Organisation Virtual Private Network (VPN) Connectivity}

The reason behind the implementation of VPN was to provide a secure method of connecting to the organisation network. To put it simply, VPN can be viewed as the immigration counter and the Internet visitors are travellers who are trying to enter the country.

\subsection{Installation and Configuration}

The solution implemented for voice communication was Skype clients. The use of Skype enables employees as mentioned earlier to call into the organisation's phone network. The enabling of the Skype client involved installation of a VoIP switch to enable Skype to access the organisation's phone network. Firewall rules were created to enable Skype traffic to access the network since the default policy for firewall is to block all traffic from the Internet. The creation of rules to enable Internet traffic must be requested. Skype handles both voice and video data and these are two types of data which consume a high amount of bandwidth. Skype operates by scanning the Internet for a high bandwidth connection based on conference sessions. It will then choose the location with the best bandwidth report as the hosting location. This is not a huge problem for home use since the number of Skype connections per broadband connection is limited, but this will definitely cause problems to a large corporate network where there are a few thousand users. To avoid network overload it was essential for a particular network policy to be configured. The mentioned policy was configured to disable Skype from using the organisation's network as a host for conference calls.

During the same period as the Skype infrastructure installation the VPN infrastructure was also setup. The solution chosen was a browser based client by Check Point, a company which provides network security products. The client was configured to enable access to applications which are required for telecommuting. The organisation provides employees with authentication information to enable them to log on to theirworkstations and various systems. The authentication information is unique to the employee and no one employee will have more than one authentication information. This was implemented to ensure that any changes in the system could be tracked, thus making the employee accountable. In addition, the single authentication information also removes the inconvenience of an employee having to keep track and to manage several authentication information at the same time. To strengthen further the security of the system a second layer of authentication is sent in the form of a text message containing a randomly generated number to the employee's mobile phone. This was implemented to combat identity theft which had occurred previously in a different scenario.

\section{Theoretical Framework}

The theoretical framework was formulated as follow after the above analysis and discussion. The framework aims to determine the driving factors for telecommuting implementation in Malaysia. 


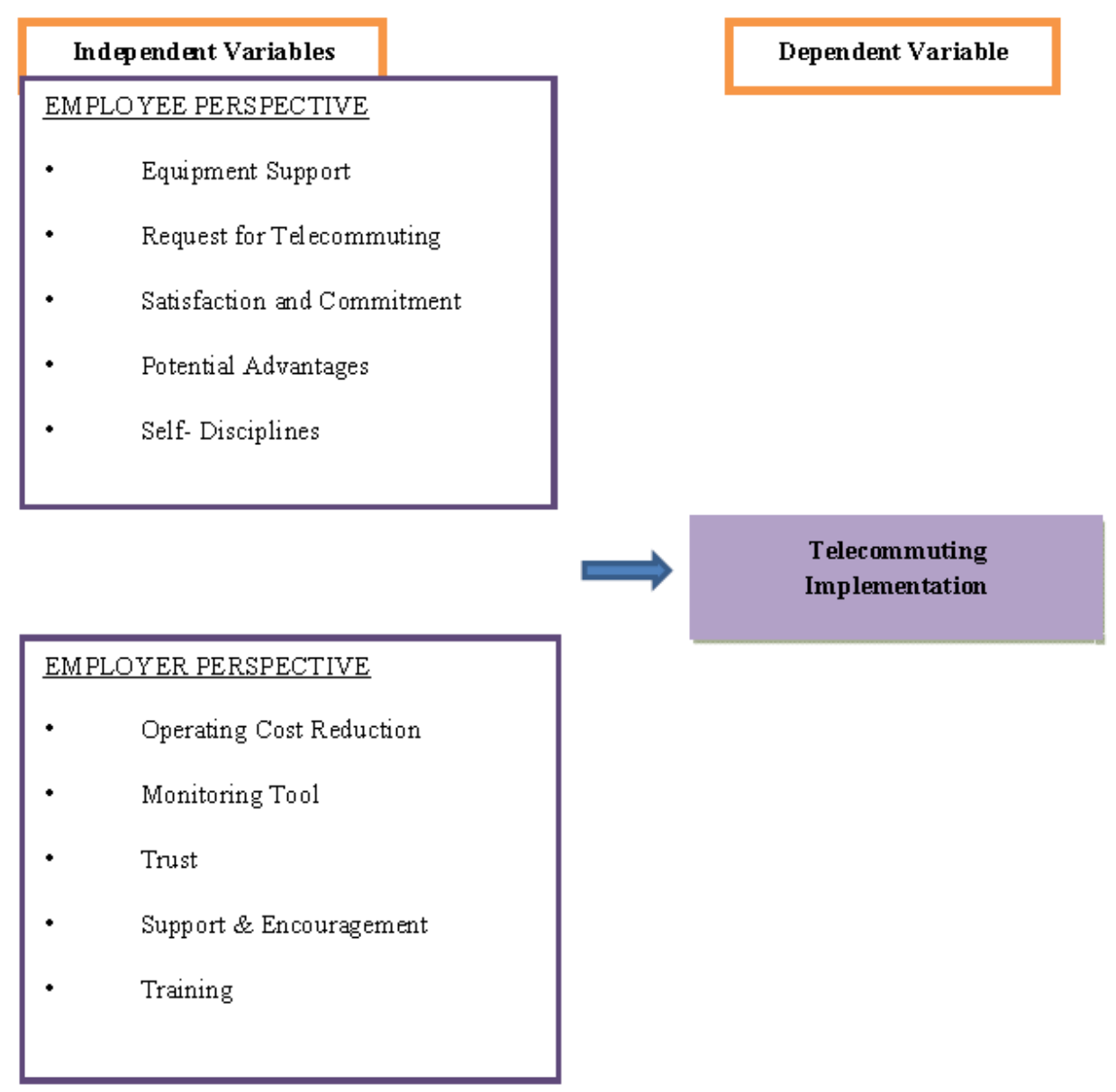

Figure 1.

\subsection{Sampling}

A 5-Likert scale Questionnaire is adopted for this research and divided into three sections:

1) Section A - Demographic details

2) Section $B-$ Awareness and involvement of Telecommuting programme

3) Section $\mathrm{C}$ - Driving factors for Telecommuting adoption

The target respondent is anybody currently working or has previously employed in any Malaysian companies. Owing to the large scope of targeted respondents, Simple Random Sampling method was selected and questionnaires were dispersed either manually or through email.

\section{Finding}

There are in total $47 \%$ targeted respondents, which amount as shown below.

\subsection{Demographic}

\begin{tabular}{llll}
\hline No. & Variables & Respondent Frequency (n) & Respondents Percentage (\%) \\
\hline 1. & Gender & 100 & 42 \\
& Male & 138 & 58 \\
& Female & & \\
2. & Respondent's Age & 147 & 61.8 \\
& $20-30$ years old & 69 & 29 \\
& $31-40$ years old & 16 & 6.7 \\
& $41-50$ years old & 6 & 2.5
\end{tabular}




\section{Organisation Sector}

$\begin{array}{lll}\text { Oil and Gas } & 23 & 9.7 \\ \text { Education } & 6 & 2.5 \\ \text { Information Technology } & 154 & 64.7 \\ \text { Telecommunication } & 16 & 6.7 \\ \text { Others } & 39 & 16.4\end{array}$

4. Position

Executive $\quad 150$

\section{0}

Manager

Senior Manager

Others

5. Organisation Type

$\begin{array}{lll}\text { Privately Owned Business } & 28 & 11.8\end{array}$

Joint Venture

$4 \quad 1.7$

Public Listed Corporation

6. Working Experience

$\begin{array}{lll}\text { Less than 1 year } & 49 & 20.6 \\ 1 \text { to } 5 \text { years } & 117 & 49.2 \\ 5 \text { to } 10 \text { years } & 43 & 18.1 \\ 10 \text { years and above } & 29 & 12.2\end{array}$

5.2 Awareness and Involvement of the Telecommuting Programme

The following table is crucial to understanding the popularity of the telecommuting programme in Malaysia. Overall, the awareness among Malaysians is satisfactory, however, their involvement in the telecommuting programme remains low and subject to further improvement.

\begin{tabular}{llcl}
\hline No. & Variables/ Characteristics & Respondent Frequency (n) & Respondents Percentage (\%) \\
\hline 1. & Telecommuting Programme Awareness & \\
& Yes & 191 & 80.3 \\
& No & 47 & 19.7
\end{tabular}

2. Knowledge about Telecommuting/Work from home

$\begin{array}{lll}\text { Initiation from company } & 126 & 52.9 \\ \text { Reading Material } & 44 & 18.5 \\ \text { Friend } & 14 & 5.9 \\ \text { Others } & 7 & 2.9 \\ \text { No answer } & 47 & 19.7\end{array}$

3. Allowed to Telecommute/Work from home

$\begin{array}{lll}\text { Yes } & 134 & 24.4\end{array}$

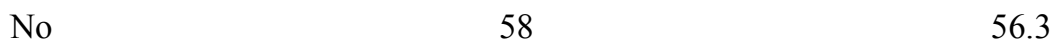

$\begin{array}{lll}\text { Neutral } & 46 & 19.3\end{array}$

4. $\quad$ Experienced in Telecommuting

Yes 102

No 36

Neutral 100

5. Number of Days in a Weekday

0.5 day

1 days

2 days

3 days

4 days

5 days

Neutral 


\section{Preferred Day in a Weekday}

$\begin{array}{lll}\text { Monday } & 41 & 17.2 \\ \text { Tuesday } & 17 & 7.1 \\ \text { Wednesday } & 19 & 8 \\ \text { Thursday } & 18 & 7.6 \\ \text { Friday } & 45 & 18.9\end{array}$

Model

Model summary

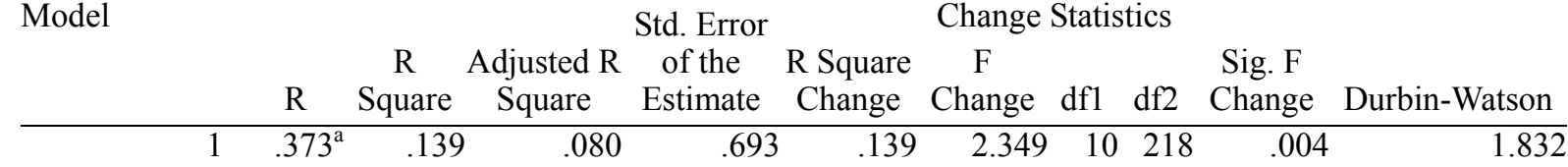

R-square: 0.139 reflecting $13.9 \%$ of telecommuting programme implementation could be predicted via 10 independent variables ranging from Employee Perspective (Basic Equipment, Request for Telecommuting, Job Satisfaction and Commitment, Potential advantages and Self-Disciplines) to Employer Perspective (Operating Cost Reduction, Monitoring Tools, Trust, Support and encouragement and finally Training)

\subsection{Summary Result}

The following is the summary of result with Beta, t-value and p-value from Multiple Regression Testing for the hypotheses of this thesis.

\begin{tabular}{|c|c|c|c|c|c|}
\hline ID & Hypothesis & Beta & t-value & p-value & Decision \\
\hline H1a: & $\begin{array}{lllll}\text { Positive relationship between } & \text { Basic } & \text { Equipment } & \text { and } \\
\text { Telecommuting implementation. } & & & \end{array}$ & 0.048 & 0.570 & 0.569 & Reject \\
\hline H1b: & $\begin{array}{l}\text { Positive relationship between Request for Telecommuting from } \\
\text { the employee and Telecommuting implementation. }\end{array}$ & 0.67 & 0.972 & 0.332 & Reject \\
\hline H1c: & $\begin{array}{l}\text { Positive relationship between Job Satisfaction/Commitment } \\
\text { and Telecommuting implementation. }\end{array}$ & 0.174 & 2.296 & 0.023 & Accept \\
\hline H1d & $\begin{array}{l}\text { Positive relationship between Potential advantages and } \\
\text { Telecommuting implementation. }\end{array}$ & 0.014 & 0.185 & 0.854 & Reject \\
\hline H1e: & $\begin{array}{l}\text { Positive relationship between Self-discipline skills and } \\
\text { Telecommuting implementation. }\end{array}$ & 0.055 & 0.749 & 0.455 & Reject \\
\hline $\mathrm{H} 2 \mathrm{a}$ : & $\begin{array}{l}\text { Positive relationship between Operating Cost Reduction and } \\
\text { Telecommuting implementation. }\end{array}$ & 0.162 & 2.253 & 0.025 & Accept \\
\hline $\mathrm{H} 2 \mathrm{~b}$ : & $\begin{array}{l}\text { Positive relationship between Monitoring Tools of } \\
\text { Telecommuting from the employee and Telecommuting } \\
\text { implementation. }\end{array}$ & 0.077 & 0.997 & 0.320 & Reject \\
\hline $\mathrm{H} 2 \mathrm{c}:$ & $\begin{array}{l}\text { Positive relationship between Trust from the Employer and } \\
\text { Telecommuting implementation. }\end{array}$ & -0.123 & -1.205 & 0.230 & Reject \\
\hline $\mathrm{H} 2 \mathrm{~d}$ & $\begin{array}{l}\text { Positive relationship between Support and encouragement and } \\
\text { Telecommuting implementation. }\end{array}$ & 0.041 & 0.402 & 0.688 & Reject \\
\hline $\mathrm{H} 2 \mathrm{e}$ : & $\begin{array}{l}\text { Positive relationship between Training and Telecommuting } \\
\text { implementation. }\end{array}$ & -0.15 & -0.216 & 0.830 & Reject \\
\hline
\end{tabular}

\subsection{Two Driving Factors Identified}

1) Job Satisfaction and Commitment Level

2) Operating Cost Reduction

The operating cost reduction is significantly associated to the telecommuting programme implementation, and is thus deemed to be a driving factor for telecommuting implementation. In addition, this finding is strongly supported from following researchers. 


\begin{tabular}{|c|c|}
\hline Authors & Facts \\
\hline $\begin{array}{ll}\text { Igbaria } & \text { and } \\
\text { Guimaraes } & \\
(1999) & \end{array}$ & $\begin{array}{l}\text { Individual sees telecommuting program as beneficial because it can reduce transportation } \\
\text { cost and time wasted owing to traffic congestion. }\end{array}$ \\
\hline $\begin{array}{l}\text { Mohammad } \\
\text { al. }(2000)\end{array}$ & Telecommuting reduces operating cost e.g. rental and utility expenses. \\
\hline $\begin{array}{l}\text { Susanne and Gill } \\
(2003)\end{array}$ & $\begin{array}{l}\text { Home-based telecommuting is reported to deliver increased productivity, reduce estate costs } \\
\text { and to increase employee morale, while for the individual it is reported to provide benefits of } \\
\text { increased autonomy in balancing "work" and "life" as well as cutting out annoying } \\
\text { commuting journeys. }\end{array}$ \\
\hline \multicolumn{2}{|c|}{$\begin{array}{l}\text { Another driving factor is job satisfaction and commitment level, which has a significant relationship with } \\
\text { Telecommuting implementation and is supported by the following research. }\end{array}$} \\
\hline Authors & Facts \\
\hline DuBrin (1991) & Higher satisfaction as a result of flexibility of working hours. \\
\hline 1. $(2002)$ & rease employee job satisfaction and co \\
\hline Diane et al. (2007) & Higher satisfaction as a result of work-life balance. \\
\hline
\end{tabular}

\section{Conclusion}

There are two significant driven forces: (1) Job Satisfaction and Commitment (2) Operating Cost Reduction have been clearly recognized for the success of Telecommuting implementation in Malaysian context.

These outcomes are consistent with previous authors (Susanne and Gill; 2003, Igbaria and Guimaraes; 1999 and Mohammad et al.; 2000) who claimed that operational cost reduction is strongly link to telecommuting implementation. Other researchers (DuBrin; 1991, Diane et al.; 2007and Haines et al.; 2002) noted that an individual has higher job satisfaction and commitment to the company owing to the telecommuting programme.

Detailed implementation steps for telecommuting have been described in this study, thus providing detailed guidance and reference for any firms who are implementing a telecommuting programme.

From the understanding of the Driving Factors and Implementation Steps, which can ensure the success of telecommuting programme implementation in Malaysia, the deployment rate of a telecommuting programme should increase and the barriers to its implementation reduced.

Exiting research only considers limited areas of driving factors from employee and employer perspective. Consequently, there is a huge study potential beyond the research constraints; e.g. factors like regulation, government incentives, technology and the nature of work.

\section{References}

Cascio, W. F. (2000). Managing a Virtual Workplace. Academy of Management Executive, 14(3), 81-90.

Clear, F., \& Lee-Kelley, L. (2005). Risk to Data Security for Small Firms Raised by Telework. IACIS Pacific 2005 Conference Proceedings, pp. 313-319.

Deeprose, D. (1999). When implementing telecommuting leave nothing to chance. HR Focus, 1(6), 50-56.

Devito, M. D. (1997, December). Blueprint for office 2000: the adventure continues. Managing Office Technology, 16-21.

DuBrin, A. J. (1991). Comparison of the job satisfaction and productivity of telecommuters versus in-house employees: a research note on work in progress. Psychological Report, 68, 1223-1234.

Fritz, M. B. W., Narasimhan, S., \& Rhee, H. S. (1998). Communication and coordination in the virtual office. Journal of Management Information Systems, 14(4), 7-28.

Goodrich, J. N. (2001). Telecommuting in America. Business Horizons, 31-36.

Guimaraes, T., \& Dallow, P. (1999). Empirically testing the benefits, problems and success factors for telecommuting programs. European Journal of Information Systems, 8(1), 40-54. http://dx.doi.org/10.1057/palgrave.ejis.3000317

Haines, V. Y. III, St. Onge, S., \& Archambault, M. (2002), Environmental and person antecedents of telecommuting outcomes. Journal of End User Computing, 14(3), 32-50. http://dx.doi.org/10.4018/joeuc.2002070103

Hill, J. E., Miller, B. C., \& Weiner, S. P. (1998). Influences of the Virtual Office on Aspects of Work and 
Work/Life Balance. Personnel Psychology, 51(3). http://dx.doi.org/10.1111/j.1744-6570.1998.tb00256.x

Hjorthol, \& Nossum (2008). Teleworking: a reduction in travel or just increased flexibility? The Journal of eWorking Archive, 2(1).

Honour, D. (2005). Teleworking - business continuity opportunities and threats. Retrieved February 5, 2010, from http://www.continuitycentral.com/feature0275.htm

Igbaria, M., \& Greenhaus, J. H. (1992). Determination of MIS employees' turnover intentions: a structural equation model. Communications of the ACM, 35(2), 34-39. http://dx.doi.org/10.1145/129630.129631

Igbaria, M., \& Guimaraes, T. (1999). Exploring differences in employee turnover intentions and its determinants among telecommuters and non-telecommuters. Journal of Management Information Systems, 16, 147-164.

Kowalski, K. B., \& Swanson, J. A. (2005). Critical Success Factors in developing teleworking programs. An International Journal, 12(3), 236-249.

Kugelmass, J. (1995). Telecommuting: A Manager's Guide to Flexible Work Arrangements. New York: Lexington Books

Kurland, N. B., \& Cooper, C. D. (2002). Manager control and employee isolation in telecommuting environments. Journal of High Technology Management Research, 13, 107-126. http://dx.doi.org/10.1016/S1047-8310(01)00051-7

Mohammad, M., Helms, M. M., \& Ross, T. J. (2000). Technological developments: shaping the telecommuting work environment of the future. Facilities, 18, 83-88. http://dx.doi.org/10.1108/02632770010312204

Patrickson, M. (2002). Teleworking: potential employment opportunities for older workers? International Journal of Manpower, 23, 704-715. http://dx.doi.org/10.1108/01437720210453902

Pemandu. (2010). The gender politics of economic competitiveness in Malaysia's transition to a knowledge economy. The Pacific Review, 24(5).

Potter, E. E. (2003). Telecommuting: the future of work, corporate culture, and American society. Journal of Labor Research, 24(1), 73-84. http://dx.doi.org/10.1007/s12122-003-1030-1

Raman, M., Ryan, T., \& Olfman, L. (2006). Knowledge Management System for Emergency Preparedness: An Action Research Study. 39th International Conference on System Sciences, Hawaii.

Siha, S. M., \& Monroe, R. W. (2006). Telecommuting's past and future: a literature review and research agenda. Business Process Management Journal, 4, 455-482. http://dx.doi.org/10.1108/14637150610678078

Svein, B. (2007). What has happened to telework? Failure, Diffusion or Modification? The Journal of e Working Archive, 1(1).

The, B. H., Loh, Y. L., \& Ong, T. S. (2012). The Acceptance and Effectiveness of Telecommuting (work from home) in Malaysia. Asia pacific Journal of Research in business management, 3(3).

Tietze, S., \& Musson, G. (2003). The times and temporalities of home-based telework. Personnel Review, 32, 438-455. http://dx.doi.org/10.1108/00483480310477524

Tremblay, D. G., \& Genin, E. (2007). The demand for telework of IT self-employed workers. The Journal of E-working, 1, 95-115.

Wang, P., Zhang, P., \& Xu, F. (2004). Research on Policies to Support Telecommuting in China. The Fourth International Conference on Electronic Business (ICEB2004) / Beijing, pp. 1368-1377.

Ward, N., \& Shabha, G. (2001). Teleworking: an assessment of socio-psychological factors. Facilities, 19(1-2), 61-70. http://dx.doi.org/10.1108/02632770110362811

Wated, M. M., \& DiSanzo, F. J. (2000). Telecommuting and organisational change: a middle managers $\begin{array}{lllll}\text { perspective. Business Process Management Journal, } & \text { 9(4), }\end{array}$ http://dx.doi.org/10.1108/14637150310484517

Yuka, S., \& Spinks, W. A. (2008). The impact of home-based telework on work-family conflict in the childcare stage. The Journal of eWorking, 2, 144-158.

\section{Copyrights}

Copyright for this article is retained by the author(s), with first publication rights granted to the journal.

This is an open-access article distributed under the terms and conditions of the Creative Commons Attribution license (http://creativecommons.org/licenses/by/3.0/). 